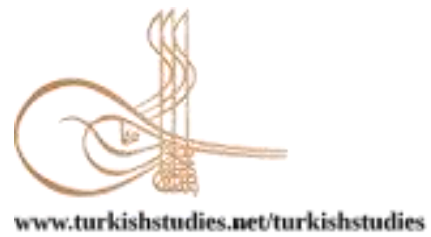

Turkish Studies

\title{
Üniversite Öğrencilerinin Karbonhidrat Tüketimi ve BKİ Değerlerinin İncelenmesi“
}

\author{
An Investigation of BMI Values and Carbohydrate Consumption of University Students
}

\author{
Mehmet Güllü** - Saime Küçükkömürler***
}

\begin{abstract}
Nutrition is one of the most important problems of university students. Diets of university students are often unbalanced and insufficient. This situation affects health and academic success of the students. High carbohydrate foods are the most consumed among this group and the amount and quality of this kind of food is quite important. In this study, it was aimed to evaluate the factors affecting the carbohydrate consumption, total energy intake, energy distribution balance and nutritional status of university students. In this context, 201 volunteers, 162 women and 39 men, who attended to Gazi University in the 2012-2013 academic year, were included in the study. The results showed that the participants mostly consume bread and pastry products, often skip meals especially breakfast, however most of them have normal BMI values ( $>0.05)$. The main reasons for skipping meals are lack of time and unwillingness. Since the participants are mostly women, it is thought that the rate of meal skipping increases with the concern of gaining weight. Despite the high rate of meal skipping, the fact that no negativity occurs at the point of nutrient and energy intake, can be attributed on that the nutrient and energy need to be taken in the skipped meals were tolerated by taking in other meals. Average and standard deviation scores were compared for the relationship between participants' gender, age, BMI values, income levels and attitudes and behaviors of meal skipping status towards taste preferences. For all comparisons, no significant relationship was detected at the level of $p<0.01$ and $p<0.05$, statistically. In addition, a significant difference was found between the sex factor and intake of energy and nutrients $(\mathrm{p}<0.05)$.
\end{abstract}

Structured Abstract: In conjunction with the development of technology, abnormal changes in the eating habits and behaviors of the society are also increasing day by day. These changes turn into eating disorders in time. University students are in the high-risk group in eating disorders (Çetin, 2017). Researches indicate that university students have not adequate and balanced nutrition for various reasons.

\footnotetext{
* Bu çalışma, Gazi Üniversitesi Bilimsel Araştırma Projeleri (BAP) Birimi tarafından 08/2011-02 numaralı proje koduyla desteklenmiştir.

** Dr. Öğr. Üyesi, Tokat Gaziosmanpaşa Üniversitesi, Zile Dinçerler Turizm İşletmeciliği ve Otelcilik Yüksekokulu, Gastronomi ve Mutfak Sanatları Bölümü

Asst. Prof., Tokat Gaziosmanpaşa University, Zile Dinçerler Tourism and Hotel Management College, Department of Gastronomy and Culinary Arts

ORCID 0000-0001-6060-1842

mehmet.gullu@gop.edu.tr

*** Prof. Dr., Osmaniye Korkut Ata Üniversitesi, Kadirli Uygulamalı Bilimler Yüksekokulu, Gastronomi ve Mutfak Sanatları Bölümü

Prof. Dr., Osmaniye Korkut Ata University, Kadirli Academy of Applied Sciences, Department of Gastronomy and Culinary Arts

ORCID 0000-0002-7893-7472

saimekkl@hotmail.com

Cite as/ Atıf: Güllü, M., Küçükkömürler, S. (2020). Üniversite öğrencilerinin karbonhidrat tüketimi ve BKİ değerlerinin incelenmesi. Turkish Studies, 15(3), 1889-1904. https://dx.doi.org/10.29228/TurkishStudies.43012

Received/Geliş: 22 April/Nisan 2020

Accepted/Kabul: 20 June/Haziran 2020

Copyright $($ ) MDE, Turkey
} 


\section{Purpose}

In this study, it was aimed to evaluate the factors affecting the carbohydrate consumption, total energy intake (BMI), energy distribution balance and nutritional status of university students.

\section{Participants}

The population of the research consists of 950 students attending Gazi University, Faculty of Vocational Education in the 2012-2013 academic year. 230 students were selected by random sampling method and included in the study. In the appraisal process of the data, it was determined that the questionnaires filled by 29 students were not answered consistently, so, these forms were excluded from the evaluation. The forms and measurements of 201 students, 162 women and 39 men, were used in the study.

\section{Data Collection and Analysis}

A questionnaire form and a daily food consumption form were used to determine demographic information and nutritional habits. Body analysis scale device was used to determine body weights and body fat percentages. The total body fat rate, body fat mass, body fat-free mass, body fluid rate, internal organs circumference fat ratio, age of metabolism and ideal fat ratios were evaluated by the portable TANITA 420BCS device. For BMI, body heights were measured with a digital height measuring device. Reference books were used to evaluate the food consumption record and to determine the nutrients in the foods. After the nutrients and amounts specified, daily consumption recorded by the "Computer Aided Nutrition Program, Nutrition Information System (BeBis)" which developed for Turkey. Daily energy and nutrient intake levels and energy expenditure levels of adolescents were determined in detail and uploaded to the SPSS (Statistical Package for Social Sciences) program. The scores of the likert scale used to measure the taste preferences of the participants are presented as mean and standard deviation. Frequency and percentage values were used for categorical variables. Student's t test was used to compare the two groups, and one-way analysis of variance (ANOVA) was used to compare three or more groups. In comparing three or more groups, Tukey multiple comparison test was used to determine which groups were statistically different. $\mathrm{p}<0.05$ and $\mathrm{p}<0.01$ values were accepted as the level of significance in all statistical analyses.

\section{Results and Discussion}

According to the results, it was observed that the participants were mostly women, were in the age range of 21-23 and most of them were in normal BMI. The results of Özkaya (2018)'s study on medical faculty students (21.75 age and 23.03 BMI, averagely) are similar to this study. In contrast, Alikaşifoğlu and Yordam (2000) stated in a study conducted in America that more than half of adults are overweight, and their BMI is more than $25 \mathrm{~kg} / \mathrm{m}^{2}$. In another study, 30.3\% of adults in Australia were found slightly overweight and $12.7 \%$ were overweight (Timperio et al., 2002). In addition, it was determined that more than half of the participants had a middle-income level and almost half of them stayed in various student dormitories. Energy and nutrient intake levels of participants were compared according to gender based on one-day food consumption records. Accordingly, a significant difference was found between total energy, sugar, protein, fat, carbohydrate, fiber, total mineral, saturated fatty acids, cholesterol and calcium intake levels, but no significant difference was found especially in terms of B group vitamins. It can be said that the gender variable is effective in the intake of energy and nutrients. However, dissimilar to these results, Yenigün (2018) and Y1ldiz (2017) found an insignificant relationship between gender factor and calorie consumption in their studies. Under normal conditions, it is known that daily energy requirement and consumption of male and female individuals are not equal. Considering that calorie consumption is directly related to calorie (energy) intake, it can be said that this different situation arises from the sample difference. According to the relationship between the ages of the participants and the nutrient and energy intakes, a significant difference was found only in the percentage of fat intake. This difference was seen between the age groups of 18-20 and 24 and over. Although there was not much difference in age groups, it can be said that this has occurred due to the energy needs of individuals at relatively young ages. Energy and nutrient intake levels of the participants were compared with BMI, but there was no statistically significant difference between them. This situation is thought to be since the participants (students) showed close BMI values and similar eating habits. Most of the participants skipped meals and generally the breakfast is the most skipped meal. Similarly, in the study conducted by Y1lmaz (2018) was found that most of the participants (76.6\%) skipped breakfast. Studies conducted by Özdoğan et al. (2012), Akdevelioğlu (2012) and Memiş (2004) have also shown that participants skipped meals similarly. Considering the participant profile, this result was as 
expected. The main reasons for skipping meals are lack of time and unwillingness, especially in breakfast and lunch. Because of the female participants, it is thought that the rate of meal skipping increases for fear of gaining weight. According to the students' attitudes and behaviors towards taste preferences, it has been observed that bread and pastry foods, sweets and sugary fruits are highly preferred in terms of consumption. More than half of the participants reported that their feelings of eating dessert during the sad and stressful periods, totally $45.3 \%$ of them prefer to have a dessert in the meal. $63.7 \%$ of the participants stated that they enjoy eating pastry foods, and totally $56.2 \%$ of them stated that they reward themselves with a dessert when everything gone well. On average, half of the participants thought that bread and dessert are indispensable for meals. In the study conducted by Ayhan (2018) on the adolescents in Malatya, similar results were obtained, and it was determined that the most consumed food was bread with a rate of $75.1 \%$. Despite the high rate of meal skipping, the fact that no negativity occurs at the point of nutrient and energy intake, can be attributed on that the nutrient and energy need to be taken in the skipped meals were tolerated by taking in other meals. Average and standard deviation scores were compared for the relationship between participants' gender, age, BMI values, income levels and attitudes and behaviors of meal skipping status towards taste preferences. For all comparisons, no significant relationship was detected at the level of $\mathrm{p}<0.01$ and $\mathrm{p}<0.05$, statistically.

In line with these results, the recommendations of the study can be listed as follows:

- This study was conducted with individuals in a range of closer age. Studies with different age groups may provide the opportunity to compare.

- In this study, the relationship between participants' carbohydrate consumption and BMI values were examined. The subject can be expanded by studies on different nutrients.

- Physical activity status and habits of the participants were not examined in the study. More extensive studies including physical activity status and habits can be conducted.

- This study comprises only the students at Gazi University. Different results can be obtained with studies for students in different provinces and universities.

- Since daily nutrient consumption is planned as a very detailed study, it has been realized by recording only one daily consumption. The same study can be continued by repeating a 3day average or at different times. By this way, it is thought that more different results can be achieved.

Keywords: Obesity, Undergraduates, BMI, Energy, Carbohydrate Consume.

Öz: Üniversitelerde öğrenim görmekte olan öğrencilerin en önemli sorunlarından birisi beslenme sorunudur. Üniversite öğrencileri değişik nedenlerle yeterli ve dengeli beslenememektedir. Bu durum öğrencilerin sağlığını ve başarı durumunu etkilemektedir. Üniversite öğrencilerinin en çok tükettikleri karbonhidrat grubu yiyeceklerdir. Bu gruptaki yiyeceklerin özelliği ve miktarı çok önemlidir. Bu çalışmada; üniversite öğrencilerinin karbonhidrat tüketimi, toplam enerji alımı, enerji dağılım dengesi, beslenme durumu ve beslenme durumunu etkileyen etmenlerin değerlendirilmesi amaçlanmıştır. Bu kapsamda; 2012-2013 eğitimöğretim yılında Gazi Üniversitesine devam eden 162'si kadın 39'u erkek olmak üzere 201 gönüllü katılımcı çalışmaya dahil edilmiştir. Çalışmadan elde edilen sonuçlar; katılımcıların ağırlıklı olarak ekmek ve hamur işi ürünleri tükettiklerini, sıkça başta sabah kahvaltısı olmak üzere ögün atladıklarını, buna rağmen çoğunun normal BKİ değerlerine sahip olduklarını göstermiştir $(p>0.05)$. Öğün atlama sebepleri arasında zaman bulamama ve yemek istememe başta gelmektedir. Katılımcıların çoğunlukla kadınlardan oluşması, kilo alma endişesiyle öğün atlama oranının yükseldiğini düşündürmektedir. Öğün atlama oranının yüksekliğine rağmen, besin ve enerji alımı noktasında hiçbir olumsuzluğun meydana gelmemesi, atlanan öğünlerde alınması gereken besin ve enerjinin diğer ögünlerde alınarak tolere edilmesine bağlanabilir. Katılımcıların cinsiyet, yaş, BKİ değerleri, gelir düzeyleri ve öğün atlama durumlarının; tat tercihlerine yönelik tutum ve davranışlarıyla olan ilişsileri için ortalama ve standart sapma puanları karşılaştırılmıştır. Tüm karşılaştırmalar için $\mathrm{p}<0.01$ ve $\mathrm{p}<0.05$ düzeyinde anlamlı herhangi bir ilişki saptanmamıştır. Ayrıca cinsiyet faktörü ile enerji ve besin öğesi alımı arasında anlamlı farklılık tespit edilmiştir $(\mathrm{p}<0.05)$.

Anahtar Kelimeler: Obezite, Üniversite Öğrencileri, BKİ, Enerji, Karbonhidrat Tüketimi. 


\section{Giriş}

Günümüz teknolojisi; tüketicinin birçok işini kolaylaştırırken, fiziksel aktivitelerini büyük miktarda azaltmıştır. Özellikle fast-foodların çoğalması, insanların zamandan kazanmalarını sağlamış ancak fazla yağlı ve karbonhidratlı yiyecek tüketimine, dolayısıyla aşırı kilo alımına ve dengesiz beslenmeye yol açmıştır (Can, 2012).

Toplumdaki yeme-içme alışkanlıkları değişmekte; çok az yeme, aşırı yeme, tek tip beslenme, aşırı fast-food tüketimi gibi alışkanlıklar giderek artmaktadır. Yeme-içme alışkanlıklarında meydana gelen bu değişimler zaman içinde yeme bozukluklarına dönüşmektedir. Üniversite öğrencileri yeme bozukluklarında yüksek riskli grubu oluşturmaktadır (Çetin, 2017). Ülkemizde üniversiteler yoğunlukla büyük şehirlerde bulunmaktadır. Üniversitelerde öğrenim görme hakkını kazanan öğrenciler Anadolu'nun değişik yerlerinden gelerek bu kurumlarda öğrenim görmeye çalışmaktadır. Üniversite öğrencilerinin başarısını etkileyen birçok etmen vardır. $\mathrm{Bu}$ etmenlerden birisi de beslenme sorunudur. $\mathrm{Bu}$ alanda yapılan araştırmalar da çeşitli nedenlerle üniversite öğrencilerinin yeterli ve dengeli beslenmediğini göstermektedir. Nitekim, Yılmaz ve Özkan (2007)'nın, Balıkesir Üniversitesi Bandırma Sağlık Yüksekokulu Hemşirelik ve Bandırma Meslek Yüksekokulu Çocuk Gelişimi bölümlerinde okuyan 180 öğrenci ile yaptığı çalışma sonuçlarına göre, öğrenciler yeterli düzeyde beslenme bilgisine sahip olmalarına karşın genellikle sağlıksız gidalara da yönelmekte, süt ve yumurta türü besinleri az tüketmekte, sebze yemeklerini daha az tercih etmekte, öğün atlamakta, yetersiz ve dengesiz olarak beslenmektedirler.

Yetişkinlerde kilogram cinsinden ağırlı̆̆ın, metre cinsinden boyun karesine oranı şişmanlığın göstergesidir (Akgün ve ark., 1997). Obezitenin saptanmasında yaygın olarak Beden Kitle İndeksi (BKİ) kullanılır (Samur ve Yıldız, 2008). Dünya Sağlık Örgütü, şişmanlığın tanımı için BKİ'yi önermektedir (Günay, 2002; Can, 2012). BKİ'ye göre şişmanlığın tanımlanmasında farklılıklar bulunmakla birlikte en yaygın sınıflamaya göre;

$\leq 19,9 \mathrm{~kg} / \mathrm{m}^{2}$ Zayif

$20,0-24,9 \mathrm{~kg} / \mathrm{m}^{2}$ Normal

$25,0-29,9 \mathrm{~kg} / \mathrm{m}^{2}$ Hafif şişman

$30,0-39,9 \mathrm{~kg} / \mathrm{m}^{2}$ şişman

$\geq 40,0 \mathrm{~kg} / \mathrm{m}^{2}$ Aşırı şişman kabul edilmektedir (Yorulmaz vd., 1995).

Dünya Sağlık Örgütü'nün BKİ sınıflamasına göre ise;

$\leq 18,4 \mathrm{~kg} / \mathrm{m}^{2}$ Düşük kilolu

$18,5-24,9 \mathrm{~kg} / \mathrm{m}^{2}$ Normal

25,0- 29,9 kg/m² Evre 1 Aşırı kilolu

30,0-39,9 kg/m² Evre 2 Aşırı kilolu

$\geq 40 \mathrm{~kg} / \mathrm{m}^{2}$ Evre 3 Aşırı kiloludur (Topbaş vd., 2000; Müftüoğlu, 2004).

BKİ değerlerinin yüksek olması, vücut yağ oranının yüksek olduğunu gösteren en önemli faktörlerden biridir. Bu durum bireyde obezite başta olmak üzere birçok hastalığın (kolesterol, kalp hastalıkları, diyabet, yüksek kan basıncı gibi) ortaya çıkma riskini arttırmaktadır (Piva vd., 2011; Gibson, 1990). Vücut yağ miktarının yüksekliği çocukluk döneminden itibaren yüksek kan basıncı için en önemli hazırlayıcı etmendir. BKİ'nin $27 \mathrm{~kg} / \mathrm{m}^{2}$ ya da daha yüksek olması ile yüksek kan basıncı arasında ilişki olduğu tespit edilmiştir (Can, 2012).

Söz konusu hastalıkların temelinde en belirgin tetikleyici olarak obezitenin var olduğunu söylemek mümkündür. Günümüzde yaygın olarak görülen obezite, artan teknolojik gelişmelere 
paralel olarak artış eğilimindedir. Obezite, dışarıdan alınan besinlerle vücuda giren enerji alımı ve yakımı arasındaki dengesizlikten dolayı vücuttaki yă̆ kitlesinin, yağsız vücut kitlesine oranla artması şeklinde tanımlanmaktadır (Hamurtekin, 2014; Samur ve Yıldız, 2008; Ashrafi, 2007). Bir başka tanımda ise, vücutta aşırı yağ depolanması ile ortaya çıkan, fiziksel ve ruhsal hastalıklara sebep olan enerji metabolizması bozulması olarak ifade edilmektedir. Her yaş grubunda görülebilen obezite, temelde kötü beslenme alışkanlıklarına bağlı olmakla birlikte, karbonhidrat ve yağ tüketiminin orantısız ve dengesizliğinden ileri gelmektedir (TEMD, 2018).

Özellikle gelişme çağındaki bireylerde enerjinin temel kaynağı olarak karbonhidratlar büyük önem taşımaktadır. Beyin ve sinir sisteminin tek enerji kaynağı olmaları sebebiyle genç yetişkinler için günlük gereksinim en az 130 g'dır. Karbonhidrat içeren besinler enerji kaynağ 1 olmasının yanı sıra içerdiği fitokimyasallar, mikro besin ögeleri ve posa ile sağlı̆̆ı olumlu etkilemektedir (Yılmaz, 2018; Tümer ve Çolak, 2012). Çavdar (2015) karbonhidratların görevlerini aşağıdaki gibi özetlemiştir;

- Karbonhidratların en önemli görevi enerji oluşturmaktır. 1 g karbonhidrat 4 kkal vermektedir. Beyin, sinir sistemi ve alyuvarlar normal şartlarda enerji kaynağ 1 olarak yalnızca bir karbonhidrat türü olan glikozu kullanır.

- Karbonhidratların yeterli miktarda alınması, proteinlerin enerji amaciyla kullanılmasını önlemektedir.

- Karbonhidratların yeterince alınması, su ve elektrolitlerin (sodyum, potasyum gibi) vücutta yeterince bulunmasını sağlar.

- Kanın asit-baz dengesinin korunmasında yardımcıdır. Çok düşük miktarda karbonhidrat alındığında bu denge bozulur.

- Karbonhidratların bir türü olan posa-lif, bağırsakların çalışmasını arttırarak dışkılamayı kolaylaştırır ve böylece kabızlığı önler.

Üniversite öğrencilerinin ucuzluk ve kolay ulaşılabilirlik gibi nedenlerle en fazla tükettiği gıda maddeleri makarna, poğaça, simit, ekmek vb. karbonhidrat yönünden zengin gıdalardır. Karbonhidratların özelliği ve tüketim miktarı oldukça önemlidir. Karbonhidratların fazla alınması vücut yağlanma oranını arttırmaktadır. Bu durumun değerlendirilmesinde dünyada yaygın olarak kullanılan yöntem Beden Kitle İndeksi (BKİ)'dir. Bu çalışmada, BKİ değerlendirmesi ile öğrencilerin zayıflık şişmanlık durumları incelenmiştir. BKİ değerlerinin normal olup olmadığının değerlendirilmesinde enerjinin dağılımı önem kazanmaktadır. Bireylerin bazal metabolizma hızı, yaşam koşulları ve yaşam ritmi de alınan enerji ve besin öğesi miktarını etkilemektedir. Bu nedenle bu çalışmada üniversite öğrencilerinin beslenme durumu ve beslenme durumunu etkileyen etmenler çok yönlü ve kapsamlı olarak değerlendirilmiştir.

Bu çalışmada; üniversite öğrencilerinin karbonhidrat tüketimi, toplam enerji alımı, enerji dağılım dengesi, beslenme durumu ve beslenme durumunu etkileyen etmenlerin değerlendirilmesi amaçlanmıştır. Çalışmadan elde edilen veriler, üniversite öğrencilerinin beslenme durumunu ve beslenme ile ilgili problemlerini ortaya koymuştur. Elde edilen sonuçların, bu konuda hizmet vermekte olan kurumlara (yurt ve okul yemekhaneleri) iletilerek öğrencilere daha iyi beslenme koşullarının tahsisi konusunda destek sağlayacağı düşünülmektedir.

\section{Yöntem}

\section{Evren ve Örneklem}

Araştırmanın evrenini 2012-2013 eğitim-öğretim yılında Gazi Üniversitesi Mesleki Eğitim Fakültesi'ne kayıtlı 950 öğrenci oluşturmuştur. Tesadüfí (Random) örnekleme yöntemiyle evren içerisinden katılımcılar seçilmiştir. Fakülteye kayıtlı ve aktif okuyan öğrencilerin tamamının çalışmaya katılma şansları eşit olmakla birlikte (Kaptan, 1998), şans verilen öğrencilerden yalnızca gönüllü 230 öğrenci çalışmaya dâhil edilmiştir. Verilerin değerlendirilmesi aşamasında 29 öğrencinin doldurduğu anketlerin tutarlı cevaplanmadığı tespit edilmiş, önemli soruları 
cevaplamadıkları belirlenmiş ve bu formlar değerlendirme dışı tutulmuştur. 162'si kadın, 39'u erkek olmak üzere toplam 201 öğrencinin formları ve ölçümleri çalışmada kullanılmıştır.

\section{Veri Toplama Araçları}

Standart demografik bilgilerin yanı sıra beslenme alışkanlıklarının tespitine yönelik olarak Garaulet ve ark., (2012) tarafından geliştirilen duyusal yeme ölçeğinin uyarlanmasıyla hazırlanan anket formu ve Sağlık Bakanlı̆̆ı'nın da kullanımını önerdiği bir günlük besin tüketim formu kullanılmıştır. Beden ağırlıkları ve vücut yağ yüzdelerinin belirlenmesi için vücut analiz tartısından faydalanılmıştır.

\section{Veri Toplama Yöntemleri}

Hazırlanan anket formları üniversite öğrencilerine yüz yüze izah edilerek uygulanmıştır. Besin tüketim kayıtlarının sağlıklı doldurulabilmesi için 24 saatlik tüketimlerine dikkat etmeleri yönünde gerekli bilgilendirmeler sağlanmıştır. Daha önce yapılan proje çalışması ile alınan ve total vücut analizi yapabilen portatif TANITA 420BCS aracı kullanılarak toplam vücut yağ oranı, vücut yağ kütlesi, vücut yağsız kütlesi, vücut sıvı oranı, iç organlar çevresi yağ oranı, metabolizma yaşı ve ideal yağ oranları değerlendirilmesi yapılmıştır. Katılımcıların BKİ tespitinin sağlıklı yapılabilmesi için boy ölçümleri yapılmıştır. Bu ölçümler dijital boy ölçme cihazı ile gerçekleştirilmiştir. Bu cihaz katılıcının boy ölçümünün hatasız olarak alınabilmesine olanak tanımaktadır. Elde edilen ölçümler günlük olarak hard disklerde depolanmış ve programların yüklü olduğu ana bilgisayara aktarılmıştır.

\section{Verilerin Analizi}

Besin tüketim kaydının değerlendirilmesinde yemeklerin içindeki besinlerin belirlenmesinde kaynak kitaplardan yararlanılmıştır. Bunun için Baysal ve ark., (1991) tarafindan derlenen besin bileşim cetveli kullanılmıştır. Besinler ve miktarları (g) belirlendikten sonra veriler Türkiye için geliştirilen "Bilgisayar Destekli Beslenme Programı, Beslenme Bilgi Sistemi (BeBis)" kullanılarak bir günlük tüketim kaydı yapılmıştır. Öğrencilerin bir günlük enerji ve besin öğeleri alım düzeyleri ve enerji harcama düzeyleri ayrıntılı olarak belirlenmiş, bu veriler program aracılı̆̆ıyla Excel ortamına aktarılmış ve daha sonra analizde kullanılmak üzere SPSS programına yüklenmiştir.

Çalışmadan elde edilen verilerin değerlendirilmesi ve tabloların oluşturulması amacıyla SPSS programı kullanılmıştır. Öğrencilerin tat tercihi konusundaki tutumlarını ölçmek amacıyla kullanılan likert tipi ölçekten elde edilen puanlar, ortalama ve standart sapma olarak sunulmuştur. Kategorik değişkenlerin sunumu için ise frekans ve yüzde değerler kullanılmıştır. Nicel değişkenlerin karşılaştırılmasında, iki grubun karşılaştırılması amacıyla t testi, üç veya daha fazla grubun karşılaştırılmasında ise tek yönlü varyans analizi (ANOVA) uygulanmıştır. Üç ve daha fazla grubun karşılaştırılması sonucunda istatistiksel olarak anlamlı bulunan sonuçlarda, farklılığın hangi gruplar arasında olduğunu belirlemek amacıyla Tukey çoklu karşılaştırma testi kullanılmıştır. Bütün istatistiksel analizlerde önemlilik seviyesi olarak $\mathrm{p}<0.05$ değeri kabul edilmiştir.

\section{Bulgular}

Çalı̧̧ma sonunda toplanan verilerin değerlendirilmesiyle elde edilen sonuçlar tablolar halinde verilmiştir. 
Tablo 1: Öğrencilerin Demografik Bilgilerinin Dağılımı

\begin{tabular}{|c|c|c|}
\hline Cinsiyet & Sayı $(n=201)$ & $\%$ \\
\hline Erkek & 39 & 19.4 \\
\hline Kadın & 162 & 80.6 \\
\hline Yaş & Sayı $(n=201)$ & $\%$ \\
\hline $18-20$ & 50 & 24.9 \\
\hline $21-23$ & 121 & 60.2 \\
\hline $24+$ & 30 & 14.9 \\
\hline BKI & Sayı $(n=201)$ & $\%$ \\
\hline Zayıf & 14 & 7.0 \\
\hline Normal & 169 & 84.1 \\
\hline Şişman & 18 & 9.0 \\
\hline Aile Gelir Düzeyi & Sayı $(n=201)$ & $\%$ \\
\hline$<1000 \mathrm{TL}$ & 53 & 26.4 \\
\hline $1001-1500 \mathrm{TL}$ & 65 & 32.3 \\
\hline$>1501 \mathrm{TL}$ & 83 & 41.3 \\
\hline Barınma Yeri & Sayı $(n=201)$ & $\%$ \\
\hline Devlet yurdu & 73 & 36.3 \\
\hline Özel yurt & 19 & 9.5 \\
\hline Aile yanı & 50 & 24.9 \\
\hline Ev Arkadaşı ile & 53 & 26.4 \\
\hline Diğer & 6 & 3.0 \\
\hline
\end{tabular}

Çalışmaya katılan 201 bireye ait çeşitli demografik özellikler tablo 1'de verilmiştir. Buna göre çalışmaya katılan öğrencilerin \%80,6'sının kadın, \%19,4'ünün erkek; \%60,2'sinin 21-23 yaş aralığında olduğu, 21 yaşından küçük ve 24 yaşında büyük öğrenci sayısının nispeten daha az olduğu; \%84,1'nin normal BKI'ne sahip olduğu; yarısından fazlasının orta gelir düzeyine sahip ailelerden geldiği; yarısına yakınının çeşitli yurtlarda kaldığı tespit edilmiştir. 
Tablo 2: Cinsiyete Göre Bireylerin Enerji ve Besin Öğesi Alma Düzeyleri

\begin{tabular}{|c|c|c|c|c|c|c|}
\hline \multirow{2}{*}{$\begin{array}{l}\text { Enerji ve Makro/Mikro Besin } \\
\text { Öğeleri }\end{array}$} & \multicolumn{2}{|c|}{ Erkek } & \multicolumn{2}{|c|}{ Kadın } & \multirow{2}{*}{$\mathrm{t}$} & \multirow{2}{*}{$\mathrm{P}$} \\
\hline & $\overline{\mathrm{X}}$ & SS & $\overline{\mathrm{X}}$ & SS & & \\
\hline Enerji (kkal) & 1947.2 & 747.7 & 1390.7 & 491.4 & 5.676 & $0.000^{* * *}$ \\
\hline Şeker (mg) & 1304.0 & 694.8 & 912.2 & 432.9 & 4.448 & $\mathbf{0 . 0 0 0}$ ** \\
\hline Protein $(\mathrm{mg})$ & 86.8 & 36.5 & 56.3 & 24.8 & 6.247 & $0.000 * *$ \\
\hline Protein $\%$ & 18.9 & 7.3 & 17.1 & 6.1 & 1.626 & 0.105 \\
\hline Yağ (gr) & 73.9 & 39.9 & 57.1 & 28.2 & 3.070 & $0.002^{* *}$ \\
\hline Yağ \% & 33.3 & 9.7 & 36.1 & 8.9 & -1.734 & 0.084 \\
\hline Karbonhidrat (gr) & 226.8 & 104.8 & 158.5 & 62.9 & 5.257 & $0.000 * *$ \\
\hline Karbonhidrat \% & 47.6 & 11.1 & 46.8 & 9.8 & .448 & 0.654 \\
\hline Lif $(\mathrm{gr})$ & 18.5 & 10.9 & 14.4 & 5.8 & 3.310 & 0.001 ** \\
\hline Mineral (gr) & 18.1 & 7.5 & 13.5 & 5.1 & 4.596 & $\mathbf{0 . 0 0 0} * *$ \\
\hline Vit A (IU) & 1152.8 & 1179.4 & 877.7 & 905.2 & 1.600 & 0.111 \\
\hline Vit D $(\mu \mathrm{g})$ & 1.3 & 1.4 & 1.5 & 4.9 & -.278 & 0.781 \\
\hline Folik asit (mg) & 112.9 & 50.9 & 84.1 & 40.2 & 3.794 & 0.000 ** \\
\hline Vit B12 (mg) & 4.0 & 2.9 & 3.3 & 2.3 & 1.632 & 0.104 \\
\hline Vit C (mg) & 78.7 & 67.2 & 69.9 & 61.4 & .796 & 0.427 \\
\hline Sodyum (mg) & 3861.9 & 1731.2 & 2718.7 & 1312.4 & 4.571 & $0.000^{* *}$ \\
\hline Potasyum (mg) & 2238.8 & 1057.6 & 1722.6 & 732.0 & 3.598 & $0.000 * *$ \\
\hline Kalsiyum (mg) & 714.9 & 429.3 & 574.0 & 308.3 & 2.358 & 0.019 * \\
\hline Demir (mg) & 11.2 & 4.8 & 8.5 & 3.3 & 4.164 & $\mathbf{0 . 0 0 0}$ ** \\
\hline Çinko (ㅆg) & 11.3 & 5.2 & 8.3 & 3.3 & 4.521 & $0.000^{* *}$ \\
\hline Bakır $(\mu \mathrm{g})$ & 1.7 & 1.0 & 1.3 & .8 & 3.007 & $0.003^{* *}$ \\
\hline Flor $(\mu g)$ & 817.4 & 651.3 & 512.1 & 310.7 & 4.292 & 0.000 ** \\
\hline İyot $(\underline{\mu g})$ & 147.0 & 76.0 & 100.5 & 68.3 & 3.728 & 0.000 ** \\
\hline Tüm şeker (g) & .3 & .5 & .5 & .8 & -1.314 & 0.190 \\
\hline Glikoz (mg) & 8.7 & 8.0 & 8.1 & 9.3 & .423 & 0.673 \\
\hline Nişasta (gr) & 145.3 & 75.1 & 96.6 & 46.2 & 5.155 & $0.000^{* *}$ \\
\hline Doymuş yağ asitleri $(\mathrm{g})$ & 27.8 & 17.4 & 20.7 & 12.6 & 2.910 & $0.004^{* *}$ \\
\hline Tekli doymamış yağ asitleri (g) & 25.3 & 14.1 & 19.6 & 9.7 & 3.011 & $\mathbf{0 . 0 0 3}{ }^{* *}$ \\
\hline Çoklu doymamış yağ asitleri (g) & 15.5 & 12.0 & 12.5 & 9.7 & 1.637 & 0.103 \\
\hline Kolesterol (mg) & 314.8 & 187.4 & 187.9 & 124.5 & 5.127 & 0.000 ** \\
\hline
\end{tabular}

${ }^{*} \mathrm{p}<0.05 \quad{ }^{* * *} \mathrm{p}<0.01$

Tablo 2'de çalışmaya katılan öğrencilerin cinsiyete göre enerji ve besin öğesi alım düzeyleri karşılaştırılmıştır. Bu karşılaştırmada 1 günlük besin tüketim kayıtları esas alınmıştır. Cinsiyete göre toplam enerji, şeker, protein, yağ, karbonhidrat, lif, toplam mineral madde, doymuş yağ asitleri ve kolesterol düzeyi arasında $\mathrm{p}<0.01$ seviyesinde anlamlı bir fark bulunmuştur. Yalnızca kalsiyum düzeyi arasında $\mathrm{p}<0.05$ seviyesinde bir fark bulunmuş; ancak özellikle B grubu vitaminleri açısından anlamlı bir fark tespit edilememiştir. B12 sadece hayvansal kaynaklarda bulunuyor, aynı zamanda hayvansal kaynaklı gıda maddelerini çok az tüketmediklerinin göstergesidir. 
Tablo 3: BKİ'ne Göre Bireylerin Enerji ve Besin Öğesi Alma Düzeyleri

\begin{tabular}{|c|c|c|c|c|c|c|c|c|c|}
\hline \multirow{2}{*}{$\begin{array}{l}\text { Enerji ve } \\
\text { Makro/Mikro Besin } \\
\text { Öğeleri }\end{array}$} & \multicolumn{2}{|c|}{ Zayıf (1) } & \multicolumn{2}{|c|}{ Normal (2) } & \multicolumn{2}{|c|}{ Şişman (3) } & \multirow[b]{2}{*}{$\mathrm{F}$} & \multirow[b]{2}{*}{$\mathbf{P}$} & \multirow[b]{2}{*}{ Tukey } \\
\hline & $\bar{x}$ & SS & $\bar{x}$ & SS & $\bar{x}$ & SS & & & \\
\hline Enerji (kkal) & 1492.8 & 448.3 & 1526.9 & 616.0 & 1237.8 & 354.1 & 1.966 & 0.143 & \\
\hline Şeker (mg) & 983.6 & 366.0 & 985.1 & 539.0 & 1021.6 & 402.7 & 0.041 & 0.960 & \\
\hline Protein (mg) & 60.7 & 18.3 & 63.3 & 31.2 & 52.6 & 22.3 & 1.067 & 0.346 & \\
\hline Protein $\%$ & 17.4 & 4.2 & 17.4 & 6.7 & 17.7 & 5.0 & 0.013 & 0.987 & \\
\hline Yă̆ (gr) & 59.7 & 20.7 & 61.9 & 33.0 & 46.3 & 16.1 & 2.037 & 0.133 & \\
\hline Yağ \% & 35.7 & 7.9 & 35.7 & 9.4 & 33.8 & 7.2 & 0.356 & 0.701 & \\
\hline Karbonhidrat (gr) & 172.9 & 60.6 & 174.3 & 80.6 & 146.9 & 54.1 & 1.018 & 0.363 & \\
\hline Karbonhidrat \% & 47.1 & 7.8 & 46.8 & 10.2 & 48.4 & 10.7 & 0.211 & 0.810 & \\
\hline Lif (gr) & 15.1 & 6.0 & 15.2 & 7.5 & 14.7 & 5.7 & 0.050 & 0.951 & \\
\hline Mineral (gr) & 15.1 & 4.8 & 14.4 & 6.1 & 13.9 & 4.5 & 0.156 & 0.855 & \\
\hline Vit A (IU) & 719.2 & 374.9 & 965.1 & 1023.5 & 776.7 & 690.0 & 0.667 & 0.514 & \\
\hline Vit D $(\underline{\mu g})$ & 1.2 & .9 & 1.6 & 4.8 & .8 & .8 & 0.290 & 0.748 & \\
\hline Folik asit (mg) & 90.6 & 35.1 & 90.1 & 45.7 & 85.5 & 31.9 & 0.092 & 0.912 & \\
\hline Vit B12 (mg) & 3.7 & 2.0 & 3.5 & 2.5 & 3.0 & 2.2 & 0.339 & 0.713 & \\
\hline Vit $C(\mathrm{mg})$ & 71.1 & 48.9 & 69.4 & 61.5 & 92.9 & 79.0 & 1.153 & 0.318 & \\
\hline Sodyum (mg) & 3246.1 & 1182.0 & 2927.7 & 1520.2 & 2823.9 & 1195.4 & 0.363 & 0.696 & \\
\hline Potasyum (mg) & 1693.3 & 568.3 & 1833.3 & 862.6 & 1824.3 & 673.0 & 0.183 & 0.833 & \\
\hline Kalsiyum (mg) & 643.7 & 282.5 & 594.4 & 340.7 & 633.5 & 370.7 & 0.224 & 0.800 & \\
\hline Demir (mg) & 8.6 & 2.6 & 9.2 & 4.0 & 8.0 & 3.0 & 0.796 & 0.453 & \\
\hline Çinko $(\underline{\mu g})$ & 8.7 & 2.4 & 9.0 & 4.0 & 8.1 & 4.1 & 0.435 & 0.648 & \\
\hline Bakır ( $\mu \mathrm{g})$ & 1.2 & .4 & 1.4 & .9 & 1.1 & .3 & 0.999 & 0.370 & \\
\hline Flor $(\mu \mathrm{g})$ & 529.5 & 153.4 & 575.5 & 425.7 & 564.1 & 473.3 & 0.081 & 0.922 & \\
\hline İyot $(\mu \mathrm{g})$ & 113.7 & 41.0 & 110.4 & 75.9 & 97.9 & 52.9 & 0.268 & 0.765 & \\
\hline Tüm şeker (g) & .5 & .7 & .4 & .7 & .9 & 1.3 & 3.955 & 0.021 & \\
\hline Glikoz (mg) & 9.5 & 7.6 & 7.8 & 8.8 & 10.8 & 12.2 & 1.073 & 0.344 & \\
\hline Nişasta (gr) & 113.0 & 41.7 & 108.3 & 58.0 & 79.1 & 41.7 & 2.340 & 0.099 & \\
\hline $\begin{array}{l}\text { Doymuş yağ asitleri } \\
\text { (g) }\end{array}$ & 22.2 & 8.8 & 22.7 & 14.7 & 16.0 & 7.0 & 1.873 & 0.156 & \\
\hline $\begin{array}{l}\text { Tekli doymamış yağ } \\
\text { asitleri (g) }\end{array}$ & 21.3 & 7.1 & 21.0 & 11.5 & 16.7 & 6.1 & 1.315 & 0.271 & \\
\hline $\begin{array}{l}\text { Çoklu doymamış yağ } \\
\text { asitleri (g) }\end{array}$ & 11.7 & 6.5 & 13.6 & 10.7 & 9.6 & 7.4 & 1.367 & 0.257 & \\
\hline Kolesterol (mg) & 220.5 & 111.6 & 214.2 & 151.8 & 190.4 & 130.7 & 0.233 & 0.792 & \\
\hline
\end{tabular}

* $\mathrm{p}<0.05 \quad{ }^{* * *} \mathrm{p}<0.01$

Tablo 3'te öğrencilerin BKİ ile enerji ve besin öğesi alım düzeyleri kıyaslanmış; ancak farklı BKI'ne sahip öğrenciler arasında istatistiksel açıdan anlamlı bir fark bulunamamıştır. Bu durumun öğrencilerin büyük çoğunluğunun normal BKİ'ne sahip ve beslenme alışkanlıklarının birbirine benzemesinden kaynaklandığı düşünülmektedir. 
Tablo 4: Yaş Gruplarına Göre Bireylerin Enerji ve Besin Öğesi Alım Düzeyleri

\begin{tabular}{|c|c|c|c|c|c|c|c|c|c|}
\hline \multirow{2}{*}{$\begin{array}{l}\text { Enerji ve } \\
\text { Makro/Mikro Besin } \\
\text { Öğeleri }\end{array}$} & \multicolumn{2}{|c|}{ 18-20 (1) } & \multicolumn{2}{|c|}{$21-23(2)$} & \multicolumn{2}{|c|}{$24+(3)$} & \multirow[b]{2}{*}{$\mathrm{F}$} & \multirow[b]{2}{*}{$\mathbf{P}$} & \multirow[b]{2}{*}{ Tukey } \\
\hline & $\bar{x}$ & SS & $\bar{x}$ & SS & $\bar{x}$ & SS & & & \\
\hline Enerji (kkal) & 1545.4 & 714.6 & 1505.5 & 579.7 & 1393.0 & 374.5 & .642 & 0.527 & \\
\hline Şeker (mg) & 924.5 & 435.3 & 1002.4 & 544.2 & 1037.4 & 532.1 & .560 & 0.572 & \\
\hline Protein $(\mathrm{mg})$ & 61.1 & 30.9 & 62.3 & 28.8 & 63.6 & 33.3 & .064 & 0.938 & \\
\hline Protein $\%$ & 16.7 & 6.1 & 17.4 & 6.3 & 18.7 & 7.0 & .959 & 0.385 & \\
\hline Yağ (gr) & 65.4 & 37.5 & 61.0 & 30.4 & 49.4 & 20.5 & 2.530 & 0.082 & \\
\hline Yă \% & 37.3 & 9.0 & 35.9 & 9.2 & 31.2 & 7.8 & 4.550 & 0.012 * & $1-3$ \\
\hline Karbonhidrat (gr) & 173.0 & 87.5 & 172.4 & 79.2 & 167.3 & 49.7 & .061 & 0.941 & \\
\hline Karbonhidrat \% & 46.1 & 10.0 & 46.6 & 10.0 & 50.1 & 10.3 & 1.767 & 0.174 & \\
\hline Lif (gr) & 15.3 & 7.4 & 15.5 & 7.5 & 13.9 & 5.7 & .567 & 0.568 & \\
\hline Mineral (gr) & 14.6 & 6.3 & 14.4 & 5.8 & 14.1 & 5.8 & .066 & 0.936 & \\
\hline Vit A (IU) & 880.4 & 891.2 & 954.6 & 991.7 & 920.8 & 1017.6 & .105 & 0.900 & \\
\hline Vit D $(\underline{\mu g})$ & 2.5 & 7.4 & 1.2 & 3.0 & 1.0 & 1.2 & 1.566 & 0.211 & \\
\hline Folik asit (mg) & 88.0 & 53.5 & 89.0 & 40.7 & 95.1 & 39.4 & .276 & 0.759 & \\
\hline Vit B12 (mg) & 3.8 & 2.8 & 3.3 & 2.4 & 3.3 & 2.3 & .726 & 0.485 & \\
\hline Vit C (mg) & 67.5 & 61.4 & 72.9 & 62.0 & 73.3 & 67.9 & .142 & 0.868 & \\
\hline Sodyum (mg) & 2851.9 & 1418.0 & 3004.0 & 1484.6 & 2832.4 & 1531.7 & .283 & 0.754 & \\
\hline Potasyum (mg) & 1871.2 & 935.7 & 1802.6 & 809.1 & 1823.3 & 732.2 & .120 & 0.887 & \\
\hline Kalsiyum (mg) & 632.2 & 334.0 & 583.7 & 333.6 & 621.4 & 371.8 & .422 & 0.656 & \\
\hline Demir (mg) & 9.7 & 4.8 & 9.0 & 3.6 & 8.0 & 2.7 & 1.862 & 0.158 & \\
\hline Çinko $(\underline{\mu g})$ & 9.4 & 4.7 & 8.8 & 3.7 & 8.3 & 3.5 & .727 & 0.485 & \\
\hline Bakır $(\mu \mathrm{g})$ & 1.5 & 1.1 & 1.4 & .8 & 1.2 & .4 & 1.028 & 0.360 & \\
\hline Flor $(\mu \mathrm{g})$ & 545.9 & 316.4 & 570.1 & 468.1 & 618.4 & 336.8 & .284 & 0.753 & \\
\hline İyot $(\mu \mathrm{g})$ & 108.6 & 86.9 & 112.6 & 66.5 & 98.8 & 67.9 & .442 & 0.644 & \\
\hline Tüm şeker (g) & .5 & .7 & .4 & .7 & .6 & 1.2 & .688 & 0.504 & \\
\hline Glikoz (mg) & 7.2 & 6.7 & 8.0 & 8.4 & 10.4 & 13.8 & 1.165 & 0.314 & \\
\hline Nişasta (gr) & 108.4 & 66.3 & 105.5 & 55.3 & 104.3 & 41.7 & .063 & 0.939 & \\
\hline Doymuş yağ a. (g) & 25.0 & 17.3 & 22.0 & 13.3 & 17.5 & 8.2 & 2.784 & 0.064 & \\
\hline $\begin{array}{l}\text { Tekli doymamış yağ } \\
\text { asitleri }(\mathrm{g})\end{array}$ & 22.2 & 11.9 & 20.9 & 11.1 & 17.2 & 7.4 & 2.034 & 0.134 & \\
\hline $\begin{array}{l}\text { Çoklu doymamış yağ } \\
\text { asitleri (g) }\end{array}$ & 13.1 & 12.0 & 13.7 & 9.9 & 10.6 & 8.3 & 1.055 & 0.350 & \\
\hline Kolesterol (mg) & 210.5 & 172.8 & 207.7 & 127.2 & 235.3 & 177.2 & .424 & 0.655 & \\
\hline
\end{tabular}

${ }^{*} \mathrm{p}<0.05 \quad$ *** $\mathrm{p}<0.01$

Tablo 4'te öğrencilerin yaşları ile enerji ve besin öğesi alım düzeyleri arasındaki ilişki verilmiştir. Buna göre alınan yağ yüzdesi ile yaş grupları arasında $\mathrm{p}<0.05$ düzeyinde anlamlı bir fark vardır. Farklılığın, 1 ve 3 numaralı (18-20 ile 24+) yaş grupları arasında olduğu görülmektedir. Nispeten daha genç yaştaki bireylerin enerji ihtiyacının fazla olması sebebiyle bu durumun gerçekleştiği söylenebilir.

Tablo 5: Öğrencilerin Öğün Atlama Durumları

\begin{tabular}{lcc}
\hline \multicolumn{1}{c}{ Öğün Atlama } & Sayı $(\mathbf{n}=\mathbf{2 0 1})$ & \% \\
\hline Evet & 79 & 39.4 \\
\hline Bazen & 61 & 30.3 \\
\hline Hayır & 61 & 30.3 \\
\hline
\end{tabular}

Tablo 5'te öğrencilerin öğün atlayıp atlamadıkları saptanmaya çalışılmış ve elde edilen veriler ışığında yaklaşık \% 70 'inin ya sürekli öğün atladığı ya da bazen öğün atladığı belirlenmiştir. Aynı soruyla birlikte öğün atlayanların en çok atladıkları öğünler ve öğün atlama sebeplerini de 
sıralamaları da istenmiştir. Buna göre \%40,3 ile sabah öğünü ve \%29,4 ile öğlen öğünü en çok atlanan ögünler olarak cevaplanmıştır. Az da olsa her iki öğünü birlikte atlayan veya sadece akşam öğününü atlayan öğrenciler de tespit edilmiştir. Öğün atlama sebeplerinin tespitine yönelik, $\% 42,8$ ile sabah kahvaltısı için zamanın yetersiz olması gerekçe gösterilmiştir. Öğlen yemeği için zaman yetersizliğini gerekçe gösterenlerin oranı ise \%18,4'tür. Öğün atlama sebepleri arasında \%34,8 ile (özellikle sabah ve öğlen) öğrencilerin yemek istememeleri gelmektedir. Katılımcıların büyük çoğunluğun kadın olması, bu durumun kilo alma korkusundan kaynaklandığını düşündürmektedir.

Tablo 6: Bireylerin Öğün Atlama Durumları ile Enerji ve Besin Değerleri Arasındaki Farklılığın Tespitine Yönelik Tukey Testi

\begin{tabular}{|c|c|c|c|c|c|c|c|c|c|}
\hline \multirow{3}{*}{$\begin{array}{l}\text { Enerji ve } \\
\text { Makro/Mikro } \\
\text { Besin Öğeleri }\end{array}$} & \multicolumn{6}{|c|}{ Bireylerin Öğün Atlama Durumları } & \multirow{3}{*}{$\mathbf{F}$} & \multirow{3}{*}{$\mathbf{P}$} & \multirow{3}{*}{ Tukey } \\
\hline & \multicolumn{2}{|c|}{ Evet } & \multicolumn{2}{|c|}{ Hayır } & \multicolumn{2}{|c|}{ Bazen } & & & \\
\hline & $\overline{\mathrm{X}}$ & SS & $\overline{\bar{x}}$ & SS & $\overline{\mathrm{X}}$ & SS & & & \\
\hline Enerji (kkal) & 1522.3 & 554.4 & 1555.4 & 631.3 & 1411.4 & 595.4 & 1.009 & 0.366 & \\
\hline Şeker (mg) & 997.0 & 574.7 & 973.6 & 502.6 & 991.5 & 454.5 & .037 & 0.964 & \\
\hline Protein $(\mathrm{mg})$ & 59.2 & 22.6 & 67.4 & 37.0 & 60.8 & 30.1 & 1.372 & 0.256 & \\
\hline Protein $\%$ & 16.7 & 5.4 & 18.0 & 7.7 & 17.8 & 6.2 & .772 & 0.463 & \\
\hline Yağ (gr) & 62.3 & 33.9 & 61.4 & 33.6 & 56.8 & 25.4 & .580 & 0.561 & \\
\hline Yağ \% & 35.3 & 9.3 & 34.7 & 9.1 & 36.8 & 8.9 & .823 & 0.440 & \\
\hline Karbonhidrat (gr) & 176.2 & 66.8 & 177.6 & 80.1 & 160.2 & 87.3 & .981 & 0.377 & \\
\hline Karbonhidrat \% & 48.0 & 9.3 & 47.2 & 10.9 & 45.5 & 10.1 & 1.008 & 0.367 & \\
\hline $\operatorname{Lif}(\mathrm{gr})$ & 15.2 & 6.9 & 15.2 & 7.5 & 15.2 & 7.5 & .000 & 1.000 & \\
\hline Mineral (gr) & 14.3 & 5.3 & 14.8 & 6.8 & 14.1 & 5.7 & .188 & 0.829 & \\
\hline Vit A (IU) & 752.7 & 640.7 & 995.0 & 977.2 & 1098.2 & 1247.5 & 2.421 & 0.091 & \\
\hline Vit D $(\underline{\mu g})$ & 1.7 & 4.6 & 1.0 & 1.0 & 1.7 & 6.1 & .472 & 0.625 & \\
\hline Folik asit (mg) & 90.3 & 38.5 & 90.3 & 50.7 & 88.3 & 43.9 & .046 & 0.955 & \\
\hline Vit B12 (mg) & 3.4 & 2.2 & 3.2 & 2.5 & 3.7 & 2.8 & .543 & 0.582 & \\
\hline Vit C (mg) & 60.6 & 53.9 & 80.2 & 72.1 & 77.1 & 61.5 & 2.054 & 0.131 & \\
\hline Sodyum (mg) & 2967.0 & 1412.2 & 2982.7 & 1626.7 & 2864.1 & 1398.9 & .119 & 0.888 & \\
\hline Potasyum (mg) & 1722.2 & 716.2 & 1924.1 & 940.4 & 1851.7 & 842.8 & 1.077 & 0.343 & \\
\hline Kalsiyum (mg) & 590.9 & 279.9 & 616.0 & 442.1 & 600.3 & 290.6 & .095 & 0.910 & \\
\hline Demir (mg) & 9.0 & 3.5 & 9.2 & 3.9 & 8.9 & 4.1 & .068 & 0.934 & \\
\hline Çinko ( $\mu \mathrm{g})$ & 8.8 & 3.2 & 9.0 & 4.6 & 8.9 & 4.2 & .021 & 0.979 & \\
\hline Bakır $(\mu \mathrm{g})$ & 1.4 & .8 & 1.4 & .8 & 1.3 & 1.0 & .124 & 0.883 & \\
\hline Flor $(\mu \mathrm{g})$ & 619.5 & 511.1 & 520.5 & 335.3 & 559.7 & 344.5 & 1.009 & 0.366 & \\
\hline İyot $(\underline{\mu g})$ & 108.3 & 58.7 & 101.3 & 72.5 & 119.4 & 86.1 & .977 & 0.378 & \\
\hline Tüm şeker (g) & .4 & .7 & .4 & .6 & .7 & .9 & 2.803 & 0.063 & \\
\hline Glikoz (mg) & 7.9 & 8.7 & 9.4 & 10.8 & 7.4 & 7.5 & .798 & 0.452 & \\
\hline Nişasta (gr) & 115.3 & 52.3 & 105.4 & 52.6 & 94.7 & 63.1 & 2.357 & 0.097 & \\
\hline $\begin{array}{l}\text { Doymuş yağ } \\
\text { asitleri }(\mathrm{g})\end{array}$ & 21.9 & 13.4 & 23.2 & 14.9 & 21.2 & 13.8 & .336 & 0.715 & \\
\hline $\begin{array}{l}\text { Tekli doymamiş } \\
\text { yağ asitleri }(\mathrm{g})\end{array}$ & 20.7 & 10.9 & 21.6 & 12.6 & 19.7 & 8.9 & .505 & 0.604 & \\
\hline $\begin{array}{l}\text { Çoklu doymamış } \\
\text { yağ asitleri (g) }\end{array}$ & 15.0 & 12.3 & 11.9 & 9.6 & 11.7 & 7.1 & 2.447 & 0.089 & \\
\hline Kolesterol (mg) & 200.0 & 152.8 & 243.8 & 149.9 & 197.4 & 134.1 & 2.007 & 0.137 & \\
\hline
\end{tabular}
${ }^{*} \mathrm{p}<0.05 \quad{ }^{* * *} \mathrm{p}<0.01$

Tablo 6'da öğrencilerin öğ̈̈n atlama durumları ile enerji ve besin öğesi alım düzeyleri arasındaki ilişki ele alınmış fakat anlamlı herhangi bir fark bulunamamıştır. Öğrencilerin öğün atlamalarına rağmen böyle bir durumun ortaya çıkma sebebi beslenme şekillerinin hamur işi ve fast-food tarzı beslenme olarak gösterilebilir. Bir öğünde almaları gereken besin öğelerini almayıp, 
bir sonraki öğünde fazla miktarda karbonhidrat, yağ ve şeker ağırlıklı beslenme sonucu öğün atlamanın çok da önemli olmadığı gibi bir kanı ortaya çıkmıştır.

Tablo 7: Öğrencilerin Tat Tercihlerine Yönelik Tutum ve Davranıșlarının Dağılımı

\begin{tabular}{|c|c|c|c|c|c|c|c|c|c|c|}
\hline \multirow{2}{*}{$\begin{array}{l}\text { TAT TERCIHINE YÖNELIK TUTUM VE } \\
\text { DAVRANIŞLAR } \\
\qquad(\mathrm{n}=201)\end{array}$} & \multicolumn{2}{|c|}{ 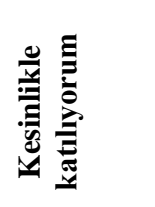 } & \multicolumn{2}{|l|}{ 章 } & \multicolumn{2}{|l|}{ 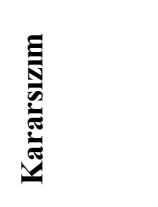 } & \multicolumn{2}{|l|}{ 至 } & \multicolumn{2}{|c|}{ 焉总 } \\
\hline & $\mathbf{n}$ & $\%$ & n & $\%$ & $\mathbf{n}$ & $\%$ & $\mathbf{n}$ & $\%$ & $\mathbf{n}$ & $\%$ \\
\hline Üzüntülü dönemlerinde tatlı yemeği isterim & 59 & 29.4 & 42 & 20.9 & 27 & 13.4 & 41 & 20.4 & 32 & 15.9 \\
\hline Stresli dönemlerinde tatlı yemeği isterim & 53 & 26.4 & 58 & 28.9 & 32 & 15.9 & 40 & 19.9 & 18 & 9.0 \\
\hline Ögün içinde mutlaka bir tatlı olmasını tercih & 39 & 19.4 & 52 & 25.9 & 38 & 18.9 & 47 & 23.4 & 25 & 12.4 \\
\hline Tatlı hamurları tercih ederim & 30 & 14.9 & 48 & 23.9 & 47 & 23.4 & 57 & 28.4 & 19 & 9.5 \\
\hline Poğaça, börek gibi tuzlu hamur işlerini severim & 35 & 17.4 & 93 & 46.3 & 32 & 15.9 & 28 & 13.9 & 13 & 6.5 \\
\hline $\begin{array}{l}\text { İşlerim iyi gittiğinde kendime ödül olarak tatlı yiyebileceğimi } \\
\text { düşünürüm }\end{array}$ & 46 & 22.9 & 67 & 33.3 & 40 & 19.9 & 36 & 17.9 & 12 & 6.0 \\
\hline Sevdiğim bir çok besin tatlıdır & 32 & 15.9 & 61 & 30.3 & 42 & 20.9 & 48 & 23.9 & 18 & 9.0 \\
\hline Meyvelerin tatlı olanlarını severim & 39 & 19.4 & 69 & 34.3 & 32 & 15.9 & 45 & 22.4 & 16 & 8.0 \\
\hline Yoğurdu ya da sütü şeker ekleyerek tüketmeyi severim & 24 & 11.9 & 34 & 16.9 & 31 & 15.4 & 47 & 23.4 & 65 & 32.3 \\
\hline Çay ya da kahveyi şekerli tüketmeyi tercih ederim & 46 & 22.9 & 58 & 28.9 & 22 & 11.0 & 32 & 15.9 & 43 & 21.4 \\
\hline Çayın yanında tatlı türü kurabiye kek tüketmeyi severim & 48 & 23.9 & 71 & 35.3 & 34 & 16.9 & 30 & 14.9 & 18 & 9.0 \\
\hline Çayın yanın da tuzlu bisküvi, börek vb. tüketmeyi severim & 50 & 24.9 & 84 & 41.8 & 34 & 16.9 & 19 & 9.5 & 14 & 7.0 \\
\hline Kahvaltıda reçel, bal, pekmez ya da helva tüketmeyi severim & 31 & 15.4 & 68 & 33.8 & 35 & 17.4 & 42 & 20.9 & 25 & 12.4 \\
\hline Bazı meyveleri şeker ekleyerek tüketmeyi severim & 19 & 9.5 & 28 & 13.9 & 22 & 11.0 & 54 & 26.9 & 78 & 38.8 \\
\hline $\begin{array}{l}\text { Ekmeğin yemekte vazgeçilemeyecek bir besin olduğunu } \\
\text { düşünürüm }\end{array}$ & 48 & 23.9 & 43 & 21.4 & 23 & 11.4 & 44 & 21.9 & 43 & 21.4 \\
\hline Yemekte ekmek yemeden doymam & 51 & 25.4 & 42 & 20.9 & 37 & 18.4 & 42 & 20.9 & 29 & 14.4 \\
\hline Yemeğin yanında pirinç pilavı olmasını isterim & 35 & 17.4 & 38 & 18.9 & 52 & 25.9 & 45 & 22.4 & 31 & 15.4 \\
\hline $\begin{array}{l}\text { Tatlı besinlerin vazgeçilemeyecek lezzetlerden olduğunu } \\
\text { düşünürüm }\end{array}$ & 43 & 21.4 & 66 & 32.8 & 41 & 20.4 & 26 & 12.9 & 25 & 12.4 \\
\hline Bulgur pilavı yerine pirinç pilavını tercih ederim & 36 & 17.9 & 45 & 22.4 & 39 & 19.4 & 47 & 23.4 & 34 & 16.9 \\
\hline
\end{tabular}

Tablo 7'de öğrencilerin tat tercihlerine yönelik tutum ve davranışlarının dağılımı verilmiştir. Buna göre öğrencilerin yarısından fazlası üzüntülü ve stresli dönemlerinde tatlı yeme hislerinin arttığını bildirirken, toplamda \%45,3'ü de öğün içerisinde mutlaka bir tatlının olmasını tercih ettiklerini belirtmiştir. Çalışmaya katılanların \%63,7'si hamur işi besinleri sevdiklerini ifade etmiş, toplamda $\% 56,2$ 'si işleri iyi gittiğinde kendisine ödül olarak tatlı aldıklarını bildirmiştir. Ekmeğin öğünlerde vazgeçilmez bir besin olduğunu düşünenlerin toplam oranı \%45,3'tür. Aynı şekilde tatlının da vazgeçilmez bir besin olduğunu ifade edenlerin toplam oranı da \%54,2'dir.

Öğrencilerin tat tercihlerine yönelik tutum ve davranışlarına bakıldığında genel anlamda ekmek ve hamur işi besinlerin, tatlı ve şekerli meyvelerin tüketim açısından halen revaçta olduğu gözlemlenmiştir.

Tablo 8: Demografik Özelliklerin, Öğün Atlama Durumu ve Tat Tercihleri ile Karşılaştırılması 


\begin{tabular}{|c|c|c|c|c|}
\hline & Sayı $(n=201)$ & Ortalama & $\mathbf{P}$ & \\
\hline \multicolumn{5}{|l|}{ Cinsiyet } \\
\hline Erkek & 39 & 62.84 & \multirow{2}{*}{0.147} & \\
\hline \multirow[t]{2}{*}{ Kadın } & 162 & 59.96 & & \\
\hline & Sayı $(n=201)$ & Ortalama & S.S. & $\mathbf{P}$ \\
\hline \multicolumn{5}{|l|}{ Yaş } \\
\hline $18-20$ & 50 & 58.32 & 12.44 & \multirow{3}{*}{0.264} \\
\hline $21-23$ & 121 & 61.35 & 10.32 & \\
\hline $24+$ & 30 & 60.86 & 11.75 & \\
\hline \multicolumn{5}{|l|}{ BKI } \\
\hline Zayıf & 14 & 61.07 & 11.26 & \multirow{3}{*}{0.294} \\
\hline Normal & 169 & 60.89 & 11.03 & \\
\hline Şişman & 18 & 56.61 & 11.61 & \\
\hline \multicolumn{5}{|c|}{ Aile Gelir Düzeyi } \\
\hline$<1000 \mathrm{TL}$ & 53 & 62.47 & 11.78 & \multirow{3}{*}{0.138} \\
\hline $1001-1500 \mathrm{TL}$ & 65 & 57.37 & 12.66 & \\
\hline$>1501 \mathrm{TL}$ & 83 & 60.66 & 8.68 & \\
\hline \multicolumn{5}{|l|}{ Öğün Atlama } \\
\hline Evet & 79 & 61.67 & 11.35 & \multirow{3}{*}{0.328} \\
\hline Hayır & 61 & 60.72 & 10.15 & \\
\hline Bazen & 61 & 58.85 & 11.68 & \\
\hline
\end{tabular}

Tablo 8'de öğrencilerin cinsiyet, yaş, BKİ değerleri, aile gelir düzeyleri ve öğün atlama durumlarının tat tercihlerine yönelik tutum ve davranışlarıyla olan ilişkileri için ortalama ve standart sapma puanları hesaplanmıştır. Tüm karşılaştırmalar için $\mathrm{p}<0.01 \mathrm{ve} p<0.05$ düzeyinde anlamlı herhangi bir ilişki saptanmamıştır.

\section{Sonuç ve Öneriler}

Üniversite öğrencilerinin karbonhidrat tüketimleri ve BKİ arasındaki ilişkinini incelenmesine yönelik olarak yapılan bu çalışmadan elde edilen sonuçlara göre; katılımcıların büyük oranda kadınlardan oluştuğu, 21-23 yaş aralığında oldukları ve normal BKI'ne sahip bireylerin ağırlıkta olduğu görülmüştür. Özkaya (2018)'in tıp fakültesi öğrencileri üzerine yaptığı çalışmada elde ettiği sonuçlar (21,75 yaş ve 23.03 BKİ ortalaması) bu çalışmayla benzerlik göstermektedir. Bunun aksine Alikaşifoğlu ve Yordam (2000); Amerika'da yapılan bir çalışmada yetişkinlerin yarısından fazlasının aşırı kilolu ve BKİ'lerinin $25 \mathrm{~kg} / \mathrm{m}^{2}$ 'den fazla olduğunu, yapılan çeşitli çalışmalarda şişmanlığın yetişkinlerde ve ergenlik çağındaki gençlerde artış gösterdiğini belirtmişlerdir. Bir diğer çalışmada ise Avustralya'daki yetişkinlerin \%30,3'ünün hafif şişman, \%12,7'sinin şişman olduğu belirlenmiştir (Timperio vd., 2002). Ayrıca katılımcıların yarısından fazlasının orta gelir düzeyine sahip ailelerden geldikleri ve yine yarısına yakınının çeşitli yurtlarda kaldığı tespit edilmiştir.

Katılımcıların cinsiyete göre enerji ve besin öğesi alım düzeyleri 1 günlük besin tüketim kayıtları esas alınarak karşılaştırılmış; toplam enerji, şeker, protein, yağ, karbonhidrat, lif, toplam mineral madde, doymuş yağ asitleri, kolesterol ve kalsiyum alım düzeyleri arasında anlamlı bir fark bulunmuş ancak özellikle B grubu vitaminleri açısından anlamlı bir fark tespit edilememiştir. B12 sadece hayvansal kaynaklarda bulunmaktadır. Bu durum aynı zamanda hayvansal kaynaklı gida maddelerini yeterince tükettiklerinin göstergesi olarak değerlendirilebilir. Cinsiyet değişkeninin enerji ve besin öğesi alımında oldukça belirleyici olduğu söylenebilir. Ancak bu sonuçlardan farklı 
olarak Yenigün (2018) ve Yıldız (2017), yaptıkları çalışmalarda cinsiyet faktörü ile kalori tüketimi arasında anlamsız bir ilişki tespit etmişlerdir. Normal şartlar altında erkek ve kadın bireyler arasında günlük enerji ihtiyacının ve tüketiminin aynı olmadığı bilinmektedir. Oysaki kalori tüketiminin, kalori (enerji) alımıyla doğrudan ilgili olduğu düşünüldüğünde ortaya çıkan bu farklı durumun örneklem farklılı̆̆ından kaynaklandığı söylenebilir. Katılımcıların yaşları ile besin öğesi ve enerji alımları arasında yalnızca alınan yağ yüzdesi arasında anlamlı bir fark bulunmuştur. Bu farklılığın 18-20 ile 24 ve üstü yaş grupları arasında olduğu görülmektedir. Yaş farkı çok olmamasına rağmen, nispeten daha genç yaştaki bireylerin enerji ihtiyacının fazla olması sebebiyle bu durumun gerçekleştiği söylenebilir.

Katılımcıların BKİ ile enerji ve besin öğesi alım düzeyleri kıyaslanmış; ancak farklı BKİ'ne sahip katılımcılar arasında istatistiksel açıdan anlamlı bir fark bulunamamıştır. Bu durumun katılımcıların (öğrencilerin) yakın BKİ değerleri göstermelerinden ve beslenme alışkanlıklarının birbirine benzemesinden kaynaklandığı düşünülmektedir.

Katılımcıların büyük çoğunluğunu öğün atladığı ve genellikle de sabah öğünün en fazla atlanan öğün olduğu belirlenmiştir. Buna benzer olarak, Yılmaz (2018)'in yaptığı çalışmada katılımcıların büyük çoğunluğunun $(\% 76,6)$ sabah kahvaltısını atladıkları tespit edilmiştir. Özdoğan vd. (2012), Akdevelioğlu (2012) ve Memiş (2004)'ün yaptıkları çalışmalar da katılımcıların benzer şekilde öğün atladıklarını göstermiştir. Katılımcı profili göz önüne alındığında ortaya çıkan sonuç beklendiği gibidir. Öğün atlama sebepleri arasında zaman yetersizliği ön plana çıkmaktadır. Ancak hem sabah hem de öğlen yemekleri için yemek istememe gerekçesinin de oldukça fazla olduğu görülmüştür. Özellikle kadın katılımcıların kilo alma korkusuyla öğün atladıkları düşünülmektedir.

Öğrencilerin tat tercihlerine yönelik tutum ve davranışlarına bakıldığında genel anlamda ekmek ve hamur işi besinlerin, tatlı ve şekerli meyvelerin tüketim açısından oldukça tercih edildiği gözlemlenmiştir. Katılımcıların yarısından fazlası üzüntülü ve stresli dönemlerinde tatlı yeme hislerinin arttığını bildirirken, toplamda \%45,3’ü de öğün içerisinde mutlaka bir tatlının olmasını tercih ettiklerini belirtmiştir. Çalışmaya katılanların \%63,7'si hamur işi besinleri sevdiklerini ifade etmiş, toplamda \%56,2'si işleri iyi gittiğinde kendisine ödül olarak tatlı aldıklarını bildirmiştir. Ekmeğin öğünlerde vazgeçilmez bir besin olduğunu düşünenlerin toplam oran1 \%45,3'tür. Ayn1 şekilde tatlının da vazgeçilmez bir besin olduğunu ifade edenlerin toplam oranı da \%54,2' dir. Ayhan (2018)'in Malatya il merkezinde adölesanlar üzerinde yaptığ bir araştırmada da benzer sonuçlar çıkmış, katılımcıların en fazla tükettikleri besin maddesinin \%75,1 oranıyla ekmek olduğu saptanmıştır. Öğün atlama oranının yüksekliğine rağmen besin öğesi ve enerji alımı noktasında herhangi bir olumsuzluğun ortaya çıkmaması, atlanan öğünlerde alınması gereken besin öğesi ve enerji ihtiyacının diğer ögünlerde fazlaca alınarak tolere edildiğine dayandırılabilir. Katılımcıların cinsiyet, yaş, BKİ değerleri, gelir düzeyleri ve ögün atlama durumlarının tat tercihlerine yönelik tutum ve davranışlarıyla olan ilişkileri için ortalama ve standart sapma puanları karşılaştırılmıştır. Tüm karşılaştırmalar için $\mathrm{p}<0.01$ ve $\mathrm{p}<0.05$ düzeyinde anlamlı herhangi bir ilişki saptanmamıştır.

Elde edilen sonuçlar doğrultusunda çalışmanın önerileri şöyle sıralanabilir:

- $\mathrm{Bu}$ çalışma birbirine çok yakın yaş aralığındaki bireylerle gerçekleştirilmiştir. Farklı yaş grupları ile yapılacak çalışmalar kıyaslama imkânı sağlayabilir.

- Bu çalışmada yalnızca katılımcıların karbonhidrat tüketimleri ile BKİ değerleri arasındaki ilişki incelenmiştir. Farklı besin öğelerine yönelik çalışmalarla konu daha da genişletilebilir.

- Çalı̧̧mada katılımcıların fiziksel aktivite durumları ve alışkanlıklarına bakılmamıştır. Fiziksel aktivite durumu ve alışkanlıklarının da yer aldığı kapsamlı çalışmalar yapılabilir.

- $\mathrm{Bu}$ çalışma yalnızca Gazi Üniversitesindeki öğrencileri kapsamaktadır. Farklı illerde ve üniversitelerdeki öğrencilere yönelik çalışmalarla çok farklı sonuçlar ortaya konabilir. 
- Günlük besin öğesi tüketimi çok ayrıntılı bir çalışma olarak planlandığından, sadece bir günlük gıda kaydı yapılarak gerçekleştirilmiştir. Aynı çalışma 3 günlük ortalama veya değişik zamanlarda tekrar edilerek devam edilebilir. Bu şekilde daha farklı sonuçlara ulaşılabileceği düşünülmektedir.

\section{Kaynakça}

Akdevelioğlu, Y. (2012). Banka Çalışanlarının Beslenme Durumlarının Değerlendirilmesi. Acıbadem Üniversitesi Sağllk Bilimleri Dergisi, 3(1): 15-20.

Akgün, S., Soyutemiz, E., Anar, Ş. ve Çıbık, R. (1997) Tüketime Sunulan Kremalı Pastaların Mikrobiyolojik Niteliklerinin Saptanmasi. Grda, 22(6):433-438.

Alikaşifoğlu A. ve Yordam, N. (2000). Obezitenin Tanımı ve Prevalansı. Katkı Pediatri Dergisi, 21(4):475-481.

Ashrafi, K. (2007). Obesity and the regulation of fat metabolism, WormBook, ed. The C. elegans Research Community, WormBook, https://doi.org/10.1895/wormbook.1.130.1

Ayhan, G. Ö. (2018). Malatya İl Merkezinde Yaşayan Liseye Devam Eden Öğrencilerin Beslenme Alışkanlıkları. Yüksek Lisans Tezi. İnönü Üniversitesi Sağlık Bilimleri Enstitüsü, Halk Sağlı̆̆ı Anabilim Dalı.

Can, S. N. (2012). Beden Kitle İndekslerine Göre Bireylerin Diyet Ürünleri Kullanım Durumları ile Bilgi Düzeylerinin Saptanması. Yüksek Lisans Tezi. Haliç Üniversitesi Sağlık Bilimleri Enstitüsü.

Çavdar, F. (2015). Beslenme. Baydem Yayıncılık.

Çetin, D. (2017). Tıp Fakültesi Öğrencilerinde Yeme Tutumunun Belirlenmesi ve Anksiyete, Sosyal Uyum, Beden Kitle İndeksi (BKİ) ve Diğer Faktörlerle İlişkisinin Değerlendirilmesi. Yüksek Lisans Tezi. Ege Üniversitesi, Sağlık Bilimleri Enstitüsü, Beslenme Bilimleri Anabilim Dalı.

Garaulet, M., Canteras, M., Morales. E., López-Guimera, G., Sánchez, D. ve Corbalán-Tutau, M.D. (2012). Validation of a questionnaire on emotional eating for use in cases of obesity; the Emotional Eater Questionnaire (EEQ). Nutr Hosp, 27:645-51.

Gibson, R.S. (1990) Principles of Nutritional Assessment. New York: Oxford University Pres.

Günay, H. (2002) Obezite Sorunu Zayıf Görünen Kişilerde de Olabilir (Obezite Derneği Başkanı Prof. Dr. Kabalak ile Söyleşi). Gıda, 7(1): 16-18.

Hamurtekin, Y. (2014). Beden Kitle İndeksi (BKI), Vücut Yağ Yüzdesi ve Abdominal Yağlanma ile Lipit Peroksidasyon İlişkisi. Yüksek Lisans Tezi. Kafkas Üniversitesi Fen Bilimleri Enstitüsü, Biyoloji Anabilim Dalı.

Kaptan, S. (1998). Bilimsel Araştırma ve İstatistik Teknikleri. 11. Bask1. Tek Iş̧1k Web Ofset

Memiş, E. (2004). Üniversite öğrencilerinde şişmanlık (obezite) durumu ve diyet ürünleri kullanmaları üzerinde bir araştırma. Yüksek Lisans Tezi. Gazi Üniversitesi Eğitim Bilimleri Enstitüsü Çocuk Gelişimi ve Ev Yönetimi Eğitimi Anabilim Dalı, Aile Ekonomisi ve Beslenme Eğitimi Bilim Dalı.

Müftüoğlu, O. (2004) Hafifleyin Gençleşin. Doğan Kitapçıllk.

Piva, S.J., Duarte, M.M., Da Cruz, I.B., Coelho, A.C., Moreira, A.P., Tonello, R., Garcia, S.C ve Moresco, R.N. (2011). Ischemia-modified albumin as an oxidative stress biomarker in obesity. Clinical Biochemistry, 44, 345-347. 
Özdoğan, Y., Özçelik, A.Ö. ve Yardımcı, H. (2012). Yurtta Kalan Üniversite Öğrencilerinin Beslenme Alışkanlıkları. Karadeniz-Blacksea-Черное море, 15:139-49.

Özkaya, M. N. (2018). Karadeniz Teknik Üniversitesi Tıp Fakültesi Öğrencilerinin Yaşadığı Ortama Göre Beden Kitle İndekslerinin ve Beslenme Paternlerinin Değerlendirilmesi. Uzmanlık Tezi. Karadeniz Teknik Üniversitesi Tıp Fakültesi, Aile Hekimliği Anabilim Dalı, Trabzon.

Samur, G. ve Yıldız, E. (2008). Obezite ve kardiyovasküler hastalıklar/hipertansiyon. Klasmat Matbaacilik.

TEMD-Türkiye Endokrinoloji ve Metabolizma Derneği, (2018). Obezite Tanı ve Tedavi Kılavuzu. 6.Bask1, Miki Matbaacılık.

Timperio, A., Crawford, D., Burns, C. ve Cameron-Smith, D. (2002). Behavior and Beliefs Related to Dietary Fat are influenced by Weight-Control Status. Journal of The American Dietetic Association, 102(1):88-91.

Topbaş, M., Elmacıŏlu, F., Dündar, C., Canbaz, S. ve Pekşen, Y. (2000). Obezite ile Günlük Tüketilen Bazı Besin Öğeleri Arasındaki İlişki. Beslenme Diyet Dergisi, 29:62-67.

Tümer, G. ve Çolak, R. (2012). Tip 2 Diabetes Mellitusda Tibbi Beslenme Tedavisi. Journal of Experimental and Clinical Medicine, 29, 12-15.

Yenigün, M. (2018). Bazı Sağlık Alanında ve Bazı Sağlık Dışı Alanda Eğitim Gören Üniversite Öğrencilerinin Beslenme Alışkanlıkları, Enerji Harcama Düzeyleri ve Etkileyen Faktörlerin Değerlendirilmesi. Yüksek Lisans Tezi. Avrasya Üniversitesi Sağlık Bilimleri Enstitüsü, Sağlık Kurumları İşletmeciliği ve Yöneticiliği Anabilim Dalı.

Yıldız, E. (2017). Tekstil İşçilerinin Beslenme Alışkanlıklarının Çalıșma Yaşamlarına Etkilerinin İncelenmesi. Yüksek Lisans Tezi. Gaziantep Üniversitesi Sosyal Bilimleri Enstitüsü, İş Sağlığı ve Güvenliği Anabilim Dalı.

Yılmaz, E. (2018). Sağlık Çalışanlarının Beslenme ve Sağlık Durumunun Tespiti: Ankara İli Örneği. Yüksek Lisans Tezi. Gazi Üniversitesi Sağlık Bilimleri Enstitüsü, Beslenme ve Diyetetik Anabilim Dal1.

Yılmaz, E. ve Özkan, S. (2007). Üniversite Öğrencilerinin Beslenme Alışkanlıklarının İncelenmesi. Firat Sağllk Hizmetleri Dergisi, 2(6):87-104.

Yorulmaz, F., Taşkınalp, O., Turut, M. ve Kutoğlu, T. (1995). 1445 Erişkin Türk İnsanında Bazı Vücut İndeksleri. Trakya Üniversitesi Tip Fakültesi Dergisi, 12(1, 2, 3):57-59. 